\title{
Development of Science Student Worksheets based on the Bio-Ecology of Cuttlefish (Sepia sp.) Cultivation to Improve Science Literacy for Junior High School Students
}

\author{
*Lalu Muhammad Imam Husaini M. Nasir, Agil Al Idrus, Agus Ramdani \\ Magister of Science Education Program, Universitas Mataram, Jl. Majapahit No.62, \\ Mataram, Indonesia, 83115 \\ *Corresponding Author e-mail: imamhusaini0@gmail.com \\ Received: June 2021; Revised: June 2021; Published: June 2021
}

\begin{abstract}
The development of the science student worksheet based on the bioecology of cuttlefish (Sepia sp.) cultivation is an effort to improve the scientific literacy skills of students at the coastal village school of East Lombok. The purpose of this research is to produce student worksheet that is feasible, practical, and effective in improving students' literacy skills. This research is research and development using Thiagarajan 4D development model which includes design, define, develop, and disseminate stages. The research subjects consisted of 1 SMP/MTs equivalent in East Lombok which were determined using purposive sampling technique. The instruments used include validation sheets, student and teacher response questionnaires, and scientific literacy assessment instruments. The feasibility and practicality data were analyzed using the percentage formula, and the effectiveness data were analyzed using the N-gain analysis. The results showed that 1) student worksheet science based on the bioecology of cuttlefish cultivation (Sepia.sp) was feasible to use with an average score of 73 for the content/material aspect, 73 for the language aspect, and 85 for the appearance aspect, 2) science student worksheet based on the bioecology of cuttlefish cultivation. (Sepia sp.) is practically used with an average percentage of student responses of $81 \%$ and teacher responses of $88 \%, 3$ ) student worksheet science based on the bioecology of cuttlefish cultivation (Sepia.sp) is effective in improving students' scientific literacy skills with an average $\mathrm{N}$ value -gain of 0.5 in the medium category. Thus, it can be concluded that the science student worksheet based on the bioecology of cuttlefish (Sepia sp.) cultivation is feasible, practical, and effective to use in science learning as an effort to improve the scientific literacy of junior high school students in coastal village schools in East Lombok.
\end{abstract}

Keywords: science student worksheets; Cuttlefish Cultivation Bioecology; Science Literacy

How to Cite: M. Nasir, L., Idrus, A., \& Ramdani, A. (2021). Development of Science Student Worksheets based on the Bio-Ecology of Cuttlefish (Sepia sp.) Cultivation to Improve Science Literacy for Junior High School Students. Prisma Sains : Jurnal Pengkajian Ilmu dan Pembelajaran Matematika dan IPA IKIP Mataram, 9(1), 76-81. doi:https://doi.org/10.33394/j-ps.v9i1.3964

https://doi.org/10.33394/j-ps.v9i1.3964

Copyright $@$ 2021, M. Nasir et al This is an open-access article under the $\mathrm{CC}$-BY License.

\section{INTRODUCTION}

Local potential in the form of marine cultivation can be used in the world of education as a material in teaching materials. The use of teaching materials in the learning process is more effective because teaching materials emphasize more on the activities of students (Setyowati et al., 2013). Teaching materials that relate the learning process to environmental content will foster students' critical, creative, communicative, and collaborative thinking skills (Karyadi, 2017). Furthermore, teaching materials sourced from the surrounding environment can serve to help students' literacy skills (Purnomo et al., 2013). It is known that the literacy ability of Indonesian students from the results of the PISA assessment in 2018 shows that Indonesia's ranking is still in a relatively low rank, namely ranking 74 out of 79 countries with a score of 396 (OECD, 2019). Therefore, the use of teaching materials sourced 
from the environment can be an important instrument in improving the literacy skills of students.

Based on the results of observations that have been carried out in coastal village schools in East Lombok, in general the teaching materials used by educators are sourced from textbooks published by the ministry. In addition, educators only use student worksheets sold in the market, and occasionally adopt student worksheets or modify the student worksheet that is downloaded via the internet. The weakness felt by the teacher using the student worksheet is that students are less enthusiastic because the examples of phenomena presented are beyond the knowledge of students.

Therefore, the use of the environment as a teaching material is expected to play a role in helping the implementation of teaching and learning activities in the classroom so that learning can attract the enthusiasm of students. One of the teaching materials that can be developed by the teacher is student worksheet. Student worksheets are printed teaching materials that can be developed by teachers in the form of sheets of paper containing material, summaries, and learning assignments that must be done by students. Student worksheets are usually used as teaching materials that make it easier for students to interact with the material provided, train students' learning independence, and make it easier for teachers to give assignments to students (Prastowo, 2015). Student worksheets developed by utilizing local potential as learning materials can provide direct experience for students in exploring information creatively and provide in-depth understanding, thus making learning more meaningful and able to improve students' critical thinking skills (Anisa, 2017). Based on this, educators are expected to be able to develop student worksheets that utilize the surrounding environment by linking the facts around students.

Based on the problems found in the observation activities in East Lombok coastal village schools, a student worksheet teaching material was developed that utilizes the local potential of the East Lombok coastal village environment in the form of squid cultivation (Sepia.sp) with floating net cage technology.

\section{METHOD}

This research is research and development. the development of student worksheet teaching materials is guided by the Thiagarajan 4D development model which has 4 stages of development, namely define, design, develop, and disseminate (Purwanto, 2013).

The define stage includes the identification stage or a preliminary study regarding the use of student worksheets in learning in coastal village schools in East Lombok. Furthermore, the design stage is a product design stage which is developed based on the results of a preliminary study. Then the finished product is designed and then carried out a feasibility test by 3 (three) expert lecturers. Then, the products that have passed the feasibility test are retested in the form of practicality tests and effectiveness tests in improving students' scientific literacy skills. The research subjects were schools in 3 (three) sub-districts in East Lombok, namely Keruak District, Jerowaru District, and Labuhan Haji District. The research subjects were determined by purposive sampling technique, namely the determination of the sample with certain considerations.

Learning is carried out using a before after research design to see the effect of using a student worksheet based on the bioecology of cuttlefish cultivation (Sepia.sp.) on students' scientific literacy skills. The learning model used is a decovery learning model which includes 6 (six) stages, namely stimulation, problem statement, data collection, data processing, verification, and generalization.

The validity instrument uses an expert validation sheet. The practical instrument uses a teacher and student response questionnaire to the use of science student worksheets integrated with scientific literacy. The effectiveness instrument uses a scientific literacy test instrument. The scientific literacy test instrument used is a multiple-choice reasoned test that refers to the scientific literacy indicators according to PISA 2018. 
The science student worksheets validity data from the validator is then calculated using the percent validity formula. The data on the practicality of the science student worksheets were analyzed using the percent validity formula. Effectiveness data in the form of scientific literacy test results tested on students were tested using normalized gain (Hake, 1999).

\section{RESULTS AND DISCUSSION}

The use of student worksheets in learning can make it easier for students to develop their knowledge, especially if it contains contextual material with the local potential of the environment around coastal village students. Student worksheets developed by utilizing local potential as learning materials can provide direct experience for students in exploring information creatively and provide in-depth understanding, thus making learning more meaningful (Anisa, 2017). So that this research raises local potential in the form of cuttlefish cultivation (Sepia.sp) as a learning material that is integrated with bioecological material or the interaction of living things with their environment.

Based on the define stage, seen from the results of observations and interviews with teachers at coastal village schools, a student worksheet that contains contextual material is needed to make it easier for students to understand the learning material. Therefore, a student worksheet based on the bioecology of cuttlefish cultivation was designed (Sepia.sp). The design phase of the student worksheet is designed to support students in improving their scientific literacy skills according to the indicators measured.

The develop stage includes a feasibility test, practicality test, and effectiveness test. Based on the feasibility test, the student worksheet based on the bioecology of cuttlefish cultivation (Sepia.sp) is feasible to be applied in science learning. Figure 1 shows the results of the feasibility test based on 3 (three) aspects of the assessment.

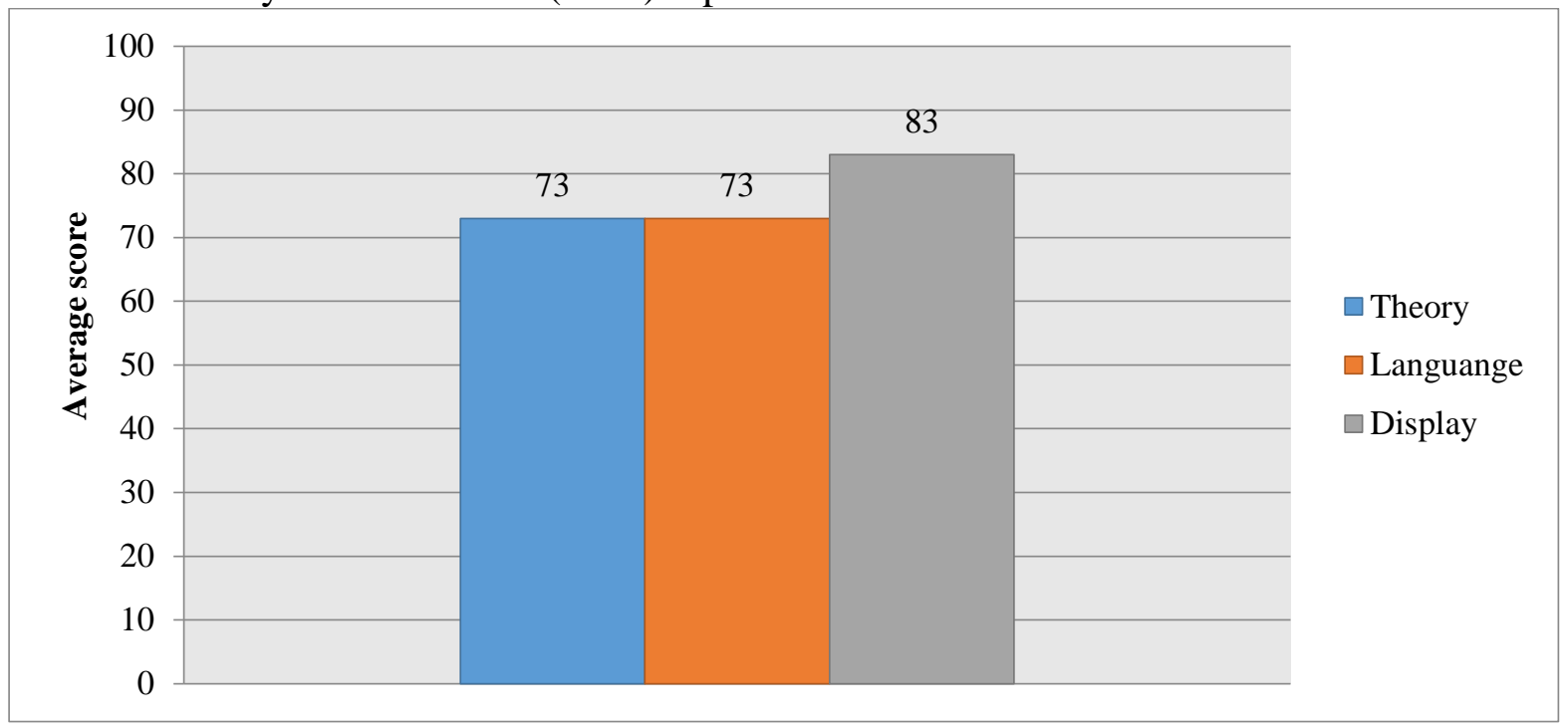

Figure 1. Eligibility Score per assessment aspect

Based on Figure 1, the distributed content/material aspect is valid with a score of 73 , then the distributed language aspect is valid with a score of 73 , and the distributed display aspect is very valid with a score of 83 . This shows that this student worksheet is feasible to use to improve students' scientific literacy.

Furthermore, a practicality test was carried out which aims to determine the ease of use of a science student worksheet based on the bioecology of cuttlefish cultivation (Sepia.sp). The practicality test is obtained through the responses of students and teachers to the use of a science student worksheet in the learning that has been carried out. Based on the response data of students and teachers, it was concluded that the science student worksheet was practically used in science learning. The practicality test data is presented in Figure 2. 


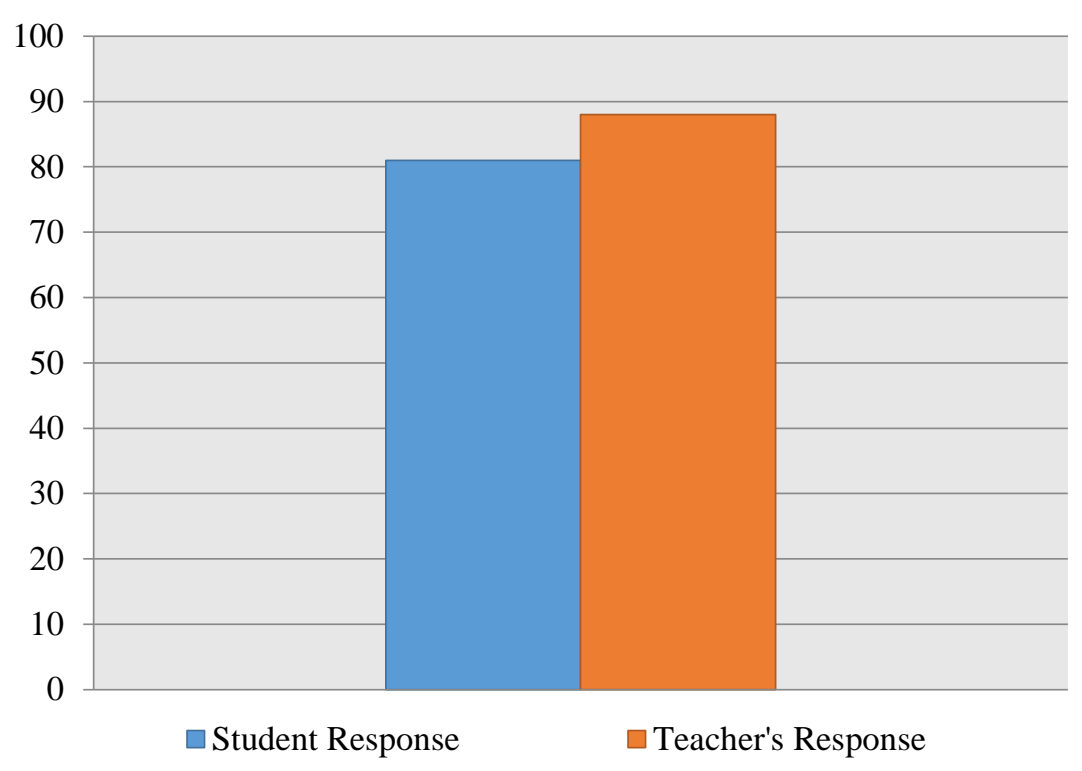

Figure 2. Comparison of the percentage of student and teacher responses

Based on Figure 2, it is obtained data that the percentage of teacher responses is higher than that of students with $88 \%$ in the very good category. This shows that the science student worksheet based on the bioecology of cuttlefish cultivation (Sepia.sp) is practical or very easy to use in science learning. Very good responses from students and teachers due to the material presented in the student worksheet contains material related to the environment around students and teachers in coastal village schools in the form of cultivation. The results of research by Darmawati et al., (2019) also showed that student worksheets based on the surrounding environment received a very good response from students with a percentage of $95 \%$.

In addition, a student worksheet effectiveness test was conducted by looking at the effect of using student worksheet science in learning on students' scientific literacy skills with a before-after research design, namely a research design that aims to compare scores before and after treatment. Based on the data analysis, it was concluded that the student worksheet science based on the bioecology of cuttlefish cultivation (Sepia .sp) was effective in increasing the scientific literacy skills of students as evidenced by the $\mathrm{N}$-gain score of 0.5 , which means an increase in the medium category.

The increase in students' scientific literacy skills is because the material presented in the student worksheet is integrated with the environment around students living on the coast in the form of squid cultivation (Sepia.sp). The use of teaching materials sourced from the surrounding environment can serve to improve the literacy skills of students (Purnomo, et al., 2013; Ramdani et al., 2020). Materials that are integrated with the surrounding environment can stimulate the curiosity of students and increase the enthusiasm of students in extracting information from the material studied in the student worksheet.

Scientific literacy data was collected using a multiple-choice reasoned test instrument. Based on the results of the analysis that has been carried out, the overall scientific literacy value of students is listed in Table 1.

Table 1. N-Gain Test Results of Science Literacy

\begin{tabular}{ccccc}
\hline \multirow{2}{*}{ Class } & \multicolumn{2}{c}{ Average } & \multirow{2}{*}{ Average N-Gain (\%) } & \multirow{2}{*}{ Effectiveness Criteria } \\
\cline { 2 - 5 } & Pre-Test & Post-test & & Medium \\
Experiment 1 & 33.47 & 82.65 & 68 & High \\
Experiment 2 & 38.87 & 88.52 & 82 & High \\
& Average & & 75 & \\
\hline
\end{tabular}


Based on Table 1, it shows that the experimental class 2 obtained an increase value with high criteria, while the experimental class 1 obtained an average increase value with medium criteria. This shows that science worksheets based on the Bioecology of Cuttlefish (Sepia sp.) Cultivation can improve students' scientific literacy.

There are 5 (five) scientific literacy indicators measured, namely 1) Remembering and applying appropriate scientific knowledge, 2) Identifying, using and producing clear models and representations, 3) changing data from one representation to another, 4) analyzing interpretations data and draw appropriate conclusions, and 5) identify assumptions, evidence, and reasons in the text related to science. The data on the results of the scientific literacy indicators are presented in Figure 3.

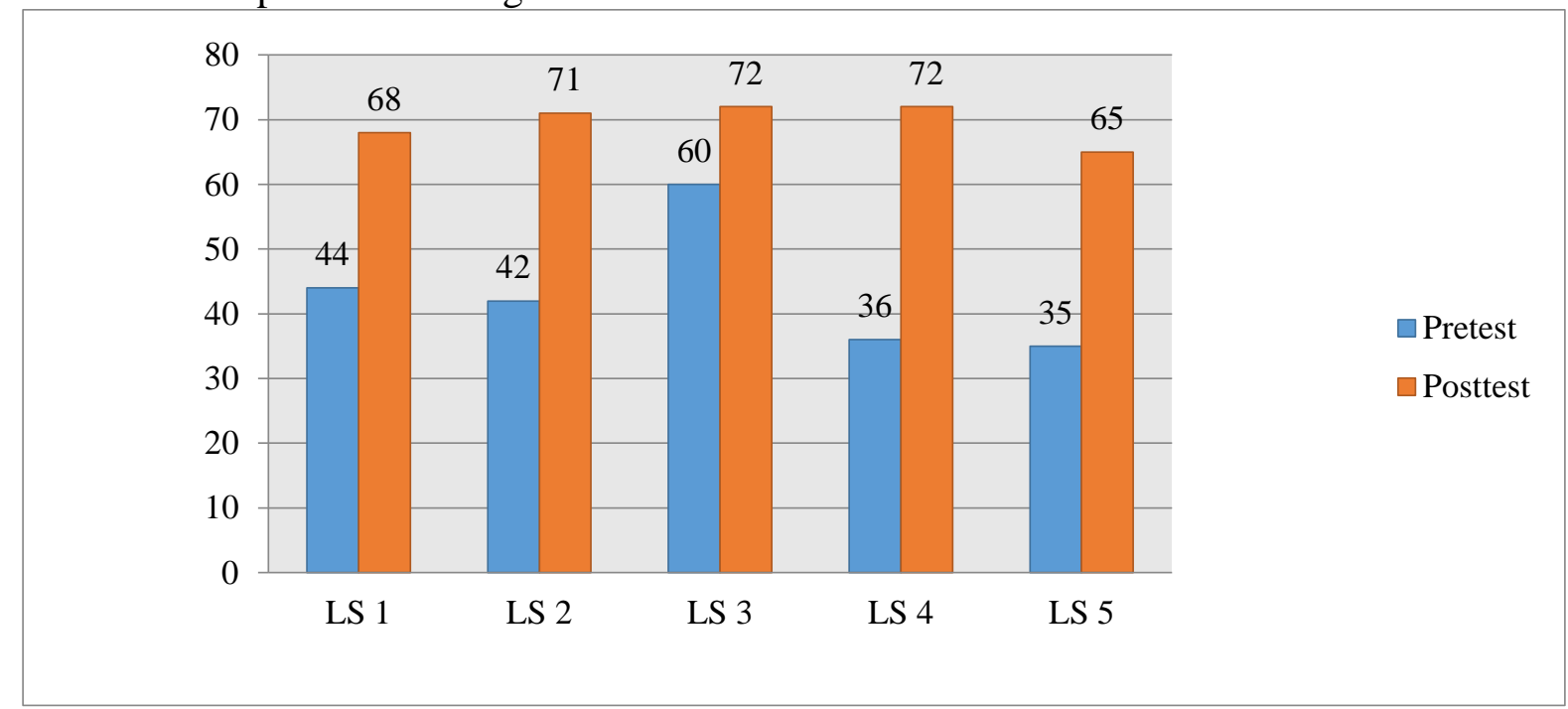

Figure 3. Comparison of the average pretest and posttest scores based on the measured scientific literacy indicators.

Based on Figure 3, the highest improvement was achieved by students on the LS4 indicator, namely analyzing data interpretation and drawing appropriate conclusions. This increase occurred because the discovery learning stages were used to train students in collecting data, processing data, proving, and drawing conclusions based on the data that had been obtained.

\section{CONCLUSION}

Based on the results of the research that has been carried out, it can be concluded that the student worksheet science based on the bioecology of cuttlefish cultivation (Sepia.sp) is feasible to use with an average score of 76 in the valid category, practical to use with an average student response of $83 \%$ and teacher response of $88 \%$ with a very practical category, and effectively used in science learning as an effort to improve the scientific literacy of junior high school students at a coastal village school in East Lombok with an $\mathrm{N}$-gain value of 75 in the high category.

\section{RECOMMENDATION}

Science teaching materials produced can be an alternative learning model applied by teachers in teaching science subjects, especially biology.

\section{ACKNOWLEDGMENT}

This research received no specific grant from any funding agency in the public,commercial, or not-for-profit sectors. 


\section{REFERENCES}

Anisa, A. (2017). Meningkatkan keterampilan berpikir kritis peserta didik melalui pembelajaran IPA berbasis potensi lokal Jepara. Jurnal Inovasi Pendidikan IPA, 3(1), $1-11$.

Dermawati, N., Suprata, S., \& Muzakkir, M. (2019). Pengembangan Lembar Kerja Peserta Didik (LKPD) Berbasis Lingkungan. JPF (Jurnal Pendidikan Fisika) Universitas Islam Negeri Alauddin Makassar, 7(1), 74-78.

Karyadi. B., Endang. W.W., Meri.S., Winda. Z. (2017). Development of Biology Learning Strategy Based on Natural Environment in the Senior High School. Conference Proceeding BICSE. 978-602-8043-84-7: 450456.

Organisation for Economic Co-operation and Development. (2018). PISA 2009 Results: What Students Know and Can Do: Student Performance in Reading, Mathematics and Science (Volume I). Paris: OECD Publishing.

Andi, P. (2011). Panduan kreatif membuat bahan ajar inovatif. Jogjakarta DIVA pres.

Purnomo, D. (2012). Pengaruh penggunaan modul hasil penelitian pencemaran di sungai pepe surakarta sebagai sumber belajar biologi pokok bahasan pencemaran lingkungan terhadap hasil belajar siswa..Jurnal Pendidikan Biologi 5(1): 59-69.

Purwanto, D. (2013). Pengembangan Media Komik IPA Terpadu Tema Pencemaran Air Sebagai Media Pembelajaran Untuk Siswa SMP Kelas VII. Pensa E-Jurnal: Pendidikan Sains, 1(01).

Ramdani, A., Jufri, A. W., \& Jamaluddin, J. (2020). Pengembangan Media Pembelajaran Berbasis Android pada Masa Pandemi Covid-19 untuk Meningkatkan Literasi Sains Peserta Didik. Jurnal Kependidikan: Jurnal Hasil Penelitian dan Kajian Kepustakaan di Bidang Pendidikan, Pengajaran dan Pembelajaran, 6(3), 433-440.

Setyowati, R. (2013). Pengembangan modul IPA berkarakter peduli lingkungan tema polusi sebagai bahan ajar siswa SMK N 11 Semarang.Unnes Science Education Journal 2 (2).

Yustiqvar, M., Hadisaputra, S., \& Gunawan, G. (2019). Analisis penguasaan konsep siswa yang belajar kimia menggunakan multimedia interaktif berbasis green chemistry. Jurnal Pijar Mscience, 14(3), 135-140. 